\title{
ARRANGEMENT OF PLAYERS POSITION IN SOCCER USING THE TECHNIQUE OF NAIVE BAYES
}

\author{
Gusti Made Trisetya Putra ${ }^{1}$; Muhammad Rusli \\ Sistem Informasi, Institut Teknologi dan Bisnis Kalbis \\ Jl. Pulomas Selatan Kav. 22, Jakarta Timur, 13210 \\ ${ }^{1}$ made.magnum@gmail.com; ${ }^{2}$ muhammad.rusli@kalbis.ac.id
}

\begin{abstract}
In the modern soccer era, soccer is already considered as an entertainment, even modern soccer already become as an industry or a business that considered can bring a great profit to the club owner. One of the most important factor in building a team is young age soccer player development. Right young age soccer player development method, can be very helpful in establish a good team. A professional team must have a coach, for the first team or junior team. The duties of a coach is determine a right position for soccer player in the game, this duties sometimes make a coach is hard to making a right decision. This research will discuss about how to design a decision support system for determine soccer player using naive bayes technique. Data mining used naive bayes technique for find a prediction for soccer player based on the player skill test result. From this research result, it can be seen that by using decision support system using data mining with naive bayes technique can be help coach performance in determine position for soccer player especially for young age soccer player development so that can help coach in the making right decision effectively and efficiently.
\end{abstract}

Keywords: analysis and design, data mining, decision support system, naive bayes, soccer

\begin{abstract}
ABSTRAK
Pada era sepak bola modern, sepak bola sudah dianggap sebagai sebuah hiburan, bahkan sepak bola modern sudah dijadikan sebagai sebuah industri atau sebuah bisnis yang dianggap dapat mendatangkan keuntungan yang besar bagi pemilik klubnya.Salah satu faktor terpenting dalam membangun sebuah tim adalah pembinaan usia muda. Metode pembinaan usia muda yang tepat, dapat sangat membantu dalam pembentukan sebuah tim yang baik. Sebuah tim yang professional pasti memiliki seorang pelatih, untuk tim utama maupun tim junior. Tugas dari seorang pelatih adalah menentukan posisi bermain seseorang yang tepat dalam permainan, tugas inilah yang terkadang membuat pelatih kesulitan untuk membuat sebuah keputusan yang tepat. Penelitian ini akan membahas tentang bagaimana merancang sebuah sistem pendukung keputusan untuk menentukan posisi seorang pemain dalam sepak bola dengan menggunakan teknik naive bayes. Teknik data mining yang digunakan adalah naive bayes untuk mencari prediksi dari posisi pemain berdasarkan hasil tes kemampuan pemain. Dari hasil penelitian ini, dapat diketahui bahwa dengan sistem pendukung keputusan menggunakan data mining teknik naive bayes dapat membantu kinerja pelatih dalam menentukan posisi pemain khususnya untuk pembinaan usia muda sehingga dapat membantu pelatih dalam pengambilan keputusan tepat secara efektif dan efisien.
\end{abstract}

Kata kunci: analisa dan perancangan, data mining, naive bayes, sepak bola, sistem pendukung keputusan 


\section{PENDAHULUAN}

Sepak bola merupakan cabang olah raga yang paling digemari di Indonesia dan di seluruh dunia. Dalam perkembangannya, sepak bola tidak dianggap sebagai sebuah cabang olah raga saja, tetapi sepak bola telah menjadi salah satu dimensi kuat dalam kehidupan manusia yang menggemari sepak bola. Pada era sepak bola modern, sepak bola sudah dianggap sebagai sebuah hiburan bahkan sepak bola modern sudah dijadikan sebagai sebuah industri atau sebuah bisnis yang dianggap dapat mendatangkan keuntungan yang besar bagi pemilik klubnya.

Dalam industri sepak bola, proses untuk membangun sebuah tim yang berkualitas, solid, dan kuat tidak ditentukan oleh kemampuan finansial suatu tim. Kekuatan finansial memang menjadi salah satu faktor untuk mengukur kesuksesan sebuah tim, walaupun bukan hal yang terpenting. Salah satu faktor terpenting dalam membangun sebuah tim adalah pembinaan usia muda. Metode pembinaan usia muda yang tepat, dapat sangat membantu dalam pembentukan sebuah tim yang baik. Pembinaan usia muda yang baik juga dijadikan salah satu indikator tim tersebut sukses dalam era industri sepak bola modern karena untuk membangun sebuah tim yang baik membutuhkan waktu bertahun-tahun.

Pembinaan usia muda dalam sepak bola modern telah menjadi suatu keharusan dalam sebuah tim. Hal ini karena pemain yang berkualitas tidak dapat dihasilkan secara seketika. Pemain yang berkualitas dihasilkan dari tahap pengembangan dan pematangan kemampuan termasuk pengalaman pemain tersebut selama bertahun-tahun. Tim-tim profesional di dunia pasti memiliki akademi pembinaan usia muda yang berjalan di bawah manajemen tim. Pembinaan usia muda juga memberikan keuntungan finansial jangka panjang sebuah tim karena sebuuah tim tidak perlu menganggarkan dana yang besar untuk membeli pemain yang sudah matang di masa depan. Tim tersebut dapat memanfaatkan pemain-pemain hasil akademi pembinaan usia muda ke dalam tim utama untuk menjadi pemain professional.

Sebuah tim yang professional pasti memiliki seorang pelatih, untuk tim utama maupun tim junior. Tugas dari seorang pelatih adalah menentukan posisi bermain seseorang yang tepat dalam permainan. Penentuan posisi ini sangatlah menentukan dalam hasil pertandingan baik itu menang ataupun kalah. Apabila pelatih tepat dalam penempatan posisi pemain, maka hasil terbaiklah yang didapat karena pemain tersebut bermain dalam posisi yang sesuai dengan kemampuannya sehingga dapat berkontribusi maksimal dalam setiap pertandingan yang dijalaninya.

Pelatih sering kesulitan dalam penentuan posisi pemain berdasarkan kemampuan dan pengalaman yang dimiliki oleh seorang pemain khususnya untuk pembinaan usia muda. Sehingga pemain tersebut tidak nyaman dalam menjalani pertandingan sehingga tidak dapat berkontribusi maksimal untuk tim. Untuk membantu kinerja para pelatih dalam pengambilan keputusan maka penelitian mengenai analisa dan perancangan sistem pendukung keputusan untuk menentukan posisi bermain yang tepat dalam sepak bola ini mencoba mmelakukan penelitian dengan menggunakan teknik Naive Bayes.

\section{METODE}

Subjek yang akan diteliti dalam penelitian ini adalah teknologi data mining untuk pembuatan rancangan sistem pendukung keputusan, penelitian ini dilakukan dengan menggunakan data kemampuan pemain yang dibagi menjadi tiga bagian yaitu, kemampuan menyerang, kemampuan bertahan, fisik, psikologi, dan kognitif.Metode pengumpulan data yang digunakan adalah dengan melakukan wawancara langsung dengan Pelatih SSB Tunas Patriot Bekasi, melakukan observasi 
langsung ke tempat latihan yaitu lapangan sepak bola, mengumpulkan dokumen-dokumen yang digunakan pada sistem yang sedang berjalan, dan tinjauan pustaka. Desain penelitian yang digunakan adalah kolerasi dan eskperimental. Penelitian ini memiliki desain kolerasi karena penelitian ini mencari kolerasi antara kemampuan pemain dengan posisi pemain dan eksperimental karena penelitian ini menghasilkan rancangan sistem pendukung keputusan untuk menentukan posisi pemain dengan teknik Naive Bayes.

Objek penelitian ini adalah Sekolah Sepak Bola (SSB) Tunas Patriot Bekasi. SSB Tunas Patriot Bekasi didirikan pada tanggal 30 Agustus 1998. SSB ini termasuk salah satu SSB yang secara resmi terdaftar di Persatuan Sepakbola Seluruh Indonesia (PSSI). Secara rutin SSB ini selalu ikut serta dalam berbagai liga, salah satunya adalah Liga Remaja Kompas. Sampai saat ini SSB Tunas Patriot memiliki sekitar 300 lebih pemain dari berbagai kelompok umur. SSB Tunas Patriot dikelola secara professional dengan kurikulum pengajaran yang tepat dan didukung dengan pelatih-pelatih yang telah memiliki sertifikasi kepelatihan yang dikeluarkan oleh PSSI. SSB Tunas Patriot memiliki jadwal latihan yang tetap dan memiliki fasilitas lapangan yang memadai sebanyak 2 lapangan. Latihan rutin SSB Tunas Patriot diadakan setiap hari rabu dan jumat jam 3 sore, dan setiap hari minggu jam 8 pagi. Latihan rutin biasanya dilakukan selama 2 jam, diawali dengan sesi pemanasan dilanjutkan dengan sesi latihan teknis dan terakhir latihan ditutup dengan sesi game. Sekretariat SSB Tunas Patriot beralamat di Kompleks GOR Kota Bekasi, Jalan Ahmad Yani No. 2. Di bawah ini adalah struktur organisasi yang berjalan di SSB Tunas Patriot Bekasi.

\section{HASIL DAN PEMBAHASAN}

\section{Sistem Pendukung Keputusan}

Konsep Sistem pendukung keputusan (Decision Support System-DSS) dimulai pada akhir tahun 1970 dengan timesharing komputer. Dengan konsep DSS, komputer dapat membantu seseorang untuk membuat sebuah keputusan untuk menyelesaikan suatu masalah tanpa harus berkonsultasi atau memerlukan bantuan dari seorang spesialis. Suatu kerangka kerja untuk mengarahkan aplikasi komputer pada pengambilan keputusan manajemen dengan mengembangkan sebuah kerangka kerja yang disebut sebagai Gorry \&Morton Grid. Matrik (Grid) ini didasarkan pada konsep mengenai keputusan terprogram dan tak terprogram serta tingkat-tingkat manajemen (Gorry \& Morton, 1971).

Sistem DSS adalah sistem berbasis komputer interaktif yang membantu pengambil keputusan dalam menggunakan data dan model untuk menyelesaikan masalah yang tidak terstruktur (Gorry \& Morton, 1971). DSS membantu pengambilan keputusan manajemen dengan menggunakan data yang telah tersimpan, model-model penyelesaian masalah, serta perangkat lunak sebagai bahan analisa untuk mendukung pengambilan keputusan yang semi atau tidak terstruktur. DSS menggabungkan pengetahuan dan pemikiran sumber daya manusia dengan kemampuan komputer untuk meningkatkan kualitas pengambilan keputusan. DSS digunakan sebagai tambahan bagi para pengambil keputusan, untuk memperluas wawasan dan memperkuat keputusan yang akan diambil, namun bukan berarti DSS digunakan sebagai sebuah jawaban pasti untuk menyelesaikan sebuah masalah apalagi untuk menggantikan fungsi dari pengambil keputusan. 


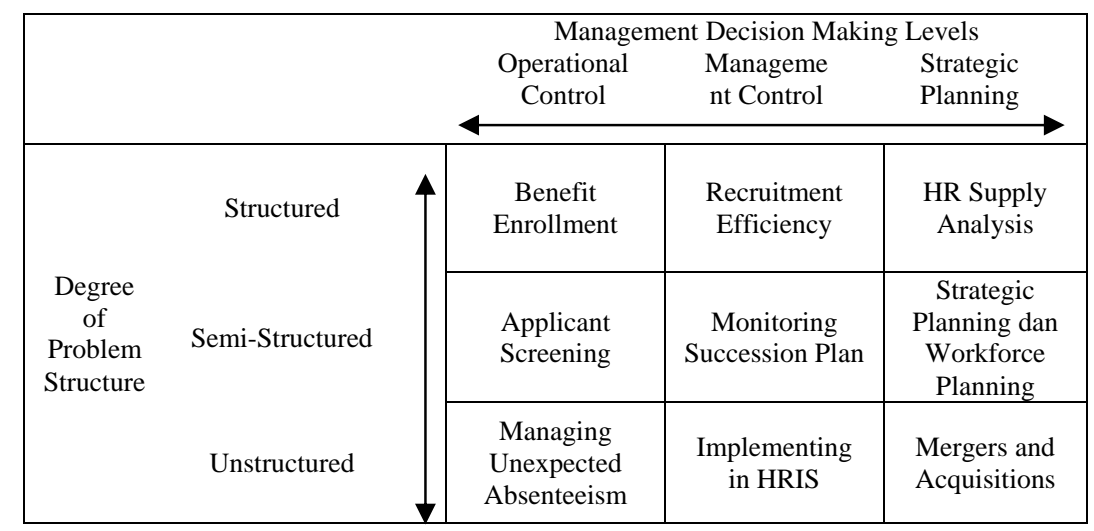

Gambar 1 Matriks Gorry dan Scott Morton (Gorry \& Morton, 1971)

Tujuan sistem pendukung keputusan adalah (Turban et. al. (2005): (1) Membantu untuk mengambil keputusan atas masalah yang terstruktur. (2) Memberikan dukungan atas pertimbangan seorang manajer, bukan untuk menggantikan fungsi manajer itu sendiri. (3) Meningkatkan efektivitas keputusan yang diambil. (4) Mempercepat waktu dan menghemat biaya dalam melakukan analisa yang membutuhkan banyak perhitungan untuk pengambilan keputusan dalam menyelesaikan sebuah masalah sehingga produktivitas meningkat. (5) Meningkatkan kualitas dari sebuah keputusan yang diambil.

Ciri-ciri sistem pendukung keputusan adalah (Kusrini, 2007): (1) Sistem pendukung keputusan ditujukan untuk membantu keputusan-keputusan yang kurang terstruktur. (2) Sistem pendukung keputusan merupakan gabungan antara kumpulan model kualitatif dan kumpulan data.(3) Sistem pendukung keputusan bersifat fleksibel dan dapat menyesuaikan dengan perubahan yang terjadi.

Beberapa karakteristik yang membedakan sistem pendukung keputusan dengan sistem informasi lain adalah: (1)Sistem pendukung keputusan dirancang untuk membantu pengambilan keputusan dalam memecahkan masalah yang bersifat semi terstruktur atau tidak terstruktur dengan menambahkan kebijaksanaan manusia dan informasi komputerisasi. (2)Sistem pendukung keputusan mengkombinasikan penggunaan model analisis dengan teknik pemasukan data konvensional serta fungsi pencari atau pemeriksa informasi. (3)Sistem pendukung keputusan dapat digunakan atau dioperasikan dengan mudah oleh orang-orang yang tidak memiliki dasar kemampuan pengoperasian komputer yang tinggi. Pendekatan yang digunakan biasanya model interaktif. (4)Sistem pendukung keputusan dirancang dengan menekankan pada aspek fleksibilitas serta kemampuan adaptasi yang tinggi sehingga dengan mudah disesuaikan dengan berbagai perubahan lingkungan yang terjadi dan kebutuhan pengguna.

Manfaat dari sistem pendukung keputusan adalah: (1) Sistem pendukung keputusan memperluas kemampuan pengambilan keputusan dalam memproses data/informasi bagi pemakainya. (2) Sistem pendukung keputusan membantu pengambilan keputusan dalam hal penghematan waktu yang dibutuhkan untuk memecahkan masalah terutama untuk masalah yang sangatkompleks dan tidak terstruktur. (3) Sistem pendukung keputusan dapat menghasilkan solusi lebih cepat dan hasilnya dapat diandalkan. (4)Sistem pendukung keputusan mungkin saja tidak mampu memecahkan masalah yang dihadapi oleh pengambil keputusan, namun sistem pendukung keputusan dapat menjadi stimulan bagi pengambil keputusan dalam memahami persoalannyakarena sistem pendukung keputusan mampu menyajikan berbagai alternatif. 


\section{Komponen Sistem Pendukung Keputusan}

Sistem pendukung keputusan dapat terdiri dari tiga subsistem utama yang menentukan kapabilitas teknis sistem pendukung keputusan (Suryadi \& Ramdhani, 1998). Ketiga subsitem tersebut adalahSubsistem Manajemen Database (Database Management Subsystem), Subsistem Manajemen Basis Model (Model Base Management Subsystem) dan Subsistem Manajemen Basis Model (Model Base Management Subsystem).

\section{Subsistem Manajemen Database (Database Management Subsystem)}

Ada beberapa perbedaan antara database untuk sistem pendukung keputusan dan non sistem pendukung keputusan. Sumber data yang digunakan untuk sistem pendukung keputusan lebih berisi banyak informasi daripada non sistem pendukung keputusan, yaitudata harus berisi faktor eksternal dan internal dari manajemen.Proses pengambilan dan ekstraksi data diambil dari sumber data yang sangat besar karena sistem pendukung keputusan membutuhkan proses ekstraksi dan database yang dalam pengelolaannya harus cukup fleksibel untuk memudahkan dalam menambah atau mengurangi data secara cepat.Dalam hal ini, kemampuan yang dibutuhkan dari manajemen database dapat diringkas sebagai berikut: (1) Kemampuan untuk mengkombinasikan berbagai variasi data melalui pengambilan dan ekstraksi data. (2) Kemampuan untuk menambahkan sumber data secara cepat dan mudah. (3) Kemampuan untuk menggambarkan struktur data logikal sesuai dengan pegertian pemakai sehingga pemakai mengetahui apa yang tersedia dan dapat menentukan kebutuhan penambahan dan pengurangan. (4) Kemampuan untuk menangani data secara personel sehingga pemakai dapat mencoba berbagai alternatif pertimbangan personel. (5) Kemampuan untuk mengelola berbagai variasi data.

\section{Subsistem Manajemen Basis Model (Model Base Management Subsystem).}

Salah satu keunggulan sistem pendukung keputusan adalah kemampuan untuk mengintegrasikan akses data dan model keputusan. Hal ini dapat dilakukan dengan menambah model keputusan ke dalam sistem informasi yang menggunakan database sebagai mekanisme integrasi dan komunikasi di antara model-model. Karakteristik ini menyatukan kekuatan pencarian dan pelaporan data.

Salah satu persoalan yang berkaitan dengan model adalah bahwa penyusunan model seringkali terikat pada struktur model yang mengasumsikan adanya masukan yang benar dan cara keluaran yang tepat. Sementara itu, model cenderung tidak mencukupi karena adanya kesulitan dalam mengembangkan model yang terintegrasi untuk menangani sekumpulan keputusan yang saling bergantungan. Cara untuk menangani persoalan ini dengan menggunakan koleksi berbagai model yang terpisah, dimana setiap model digunakan untuk menangani bagian yang berbeda dari masalah yang dihadapi. Komunikasi antara berbagai model yang saling berhubungan diserahkan kepada pengambil keputusan sebagai proses intelektual dan manual.

Salah satu pandangan yang lebih optimistis berharap untuk bisa menambahkan model-model ke dalam sistem informasi dengan database sebagai mekanisme integrasi dan komunikasi di antara mereka.Kemampuan yang dimiliki subsistem basis model meliputi hal-hal sebagai berikut: (1) Kemampuan untuk menciptakan model-model baru secara cepat dan mudah. (2) Kemampuan untuk mengakses dan mengintegrasikan model-model keputusan. (3) Kemampuan untuk mengelola basis model yang fungsi manajemen yang analog dan manajemen database (seperti mekanisme untuk menyimpan, membuat dialog, menghubungkan, dan mengakses model). 


\section{Subsistem Perangkat Lunak Penyelenggara Dialog (Dialogue Generation and Management Software).}

Fleksibilitas dan kekuatan karakteristik sistem pendukung keputusan timbul dari kemampuan interaksi antara sistem dan pengguna, yang dinamakan subsistem dialog. Bennet mendefinisikan pengguna, terminal, dan sistem perangkat lunak sebagai komponen dari sistem dialog sehingga subsistem dialog terbagi menjadi tiga bagian sebagai berikut (Suryadi \& Ramdhani, 1998): (1) Bahasa aksi, dalam hal ini adalah alat-alat yang digunakan oleh pengguna untuk melakukan interaksi dengan sistem. Sebagai contoh papan ketik (keyboard), panel sentuh, joystick, perintah suara dan sebagainya. (2) Bahasa tampilan dan presentasi, meliputi alat yang digunakan sistem sebagai media untuk menampilkan isi dari sistem kepada pengguna. Bahasa tampilan meliputi pilihan seperti printer, tampilan layar, grafik, warna, plotter, keluaran suara, dan sebagainya. (3) Basis pengetahuan, meliputi apa yang harus diketahui oleh penguna agar pengguna sistem bisa efektif. Basis pengetahuan bisa berada dalam pikiran pengguna, pada kartu referensi atau petunjuk, dalam buku manual, dan sebagainya.

Kombinasi dari kemampuan-kemampuan di atas terdiri dari apa yang disebut gaya dialog, misalnya pendekatan tanya jawab, bahasa perintah, menu, dan mengisi tempat kosong.Kemampuan yang harus dimiliki sistem pendukung keputusan untuk mendukung dialog pengguna atau sistem meliputi hal-hal sebagai berikut:(1) Kemampuan untuk menangani berbagai variasi dialog, bahkan jika mungkin untuk mengkombinasikan berbagai gaya dialogsesuai dengan pilihan pengguna. (2)Kemampuan untuk mengakomodasi tindakan pemakai dengan berbagai peralatan masukan. (3)Kemampuan untuk menmpilkan data dengan berbagai variasi format dan peralatan keluaran. (4) Kemampuan untuk memberikan dukungan yang fleksibel untuk mengetahui basis pengetahuan pengguna.

\section{Pengembangan Sistem}

Pengembangan sistem dapat berati menyusun suatu sistem yang baru untuk menggantikan sistem lama secara keseluruhan atau memperbaiki sistem yang telah ada. Sistem lama perlu diperbaiki atau diganti disebabkan karena beberapa hal yaitu sebagai berikut: (1) Adanya permasalahan yang timbul di sistem yang lama. Permasalahan tersebut dapat berupa ketidakberesan pada sistem yang lama tidak dapat berjalan atau berfungsi sebagaimana diharapkan dan pertumbuhan organisasi yang menyebabkan harus disusunnya suatu sistem yang baru. Pertumbuhan organisasi diantaranya adalah kebutuhan informasi yang semakin luas dan volume pengolahan data yang semakin meningkat. (2) Untuk meraih kesempatan. Organisasi mulai merasakan bawa teknologi informasi perlu digunakan utuk meningkatkan penyediaan informasi sehingga dapat mendukung dalam proses pengambilan keputusan yang akan dilakukan oleh manajemen. (3) Adanya instruksi atau desakan dari organisasi. Penyusunan sistem yang baru dapat pula terjadi karena adanya instruksi dari pimpinan atau dari luar organisasi karena ada permasalahan, kesempatan atau instruksi. Sistem yang baru perlu dikembangkan untuk memecahkan permasalahan yang timbul, meraih kesempatan yang ada atau memenuhi instruksi yang diberikan. Dengan adanya sistem yang baru diharapkan terjadi peningkatan seperti informasipeningkatan terhadap kualitas informasi yang disajikan, kinerja sistem sehingga menjadi lebih efektifdan peningkatan terhadap efisiensi operasi.

Dalam pengembangan sistem dikenal sebuah sistematika untuk mengembangkan sebuah sistem untuk menyelesaikan sebuah masalah yang dikenal sebagai System Development Life Cycle (SDLC). SDLCadalah sebuah fase pendekatan untuk analisis dan desain yang dimiliki dengan sistem paling baik dikembangkan melalui penggunaan sebuah siklus aktivitas analis dan user yang spesifik (Kendall \& Kendall, 2005).

Dari beberapa metode SDLC yang ada, metode SDLC yang paling sering digunakan adalah waterfall. Inti dari metode waterfall adalah pengerjaan dari suatu pengembangan sistem dilakukan secara berurutan atau secara linear. Tahapan-tahapan dalam mengembangkan System Development 
Life Cycle (SDLC) dengan waterfall adalah: (1) Identifikasi masalah, peluang, dan objektif.Dalam fase pertama SDLC, analisis berkonsentraasi dengan pengidentifikasian masalah, peluang, dan objektif. Fase ini sangat penting terhadap kesuksesan keseluruhan proyek. Fase pertama mengharuskan analis untuk melihat secara jujur apa yang terjadi dalam sebuah bisnis. Kemudian, bersama dengan anggota organisasi, analis membuat poin-poin masalah. (2) Menentukan kebutuhan informasi.Dalam fase ini analis berjuang untuk memahami informasi apa yang dibutuhkan oleh user untuk melakukan pekerjaannya. Untuk menyelesaikan fase ini, analis harus memahami bagaimana bisnis itu berjalan dan memiliki informasi lengkap mengenai orang, tujuan, data, dan prosedur yang terlibat. (3) Menganalisa kebutuhan sistem.Pada poin ini sistem analisis mempersiapkan sebuah proposal sistem yang merangkum hal-hal yang ditemukan, biaya yang tersedia/ analisis manfaat alternatif, dan membuat beberapa rekomendasi apa yang seharusnya dilakukan. Jika salah satu rekomendasi diterima oleh manajemen, analis melanjutkan proses tersebut. Setiap masalah sistem adalah unik, dan tidak pernah terdapat hanya satu solusi yang benar. Cara sebuah rekomendasi atau solusi diformulasikan tergantung pada kualitas individual dan pelatihan profesional setiap analis. (4) Mendesain sistem yang direkomendasikan.Dalam fase ini, sistem analis menggunakan informasi yang telah dikumpulkan sebelumnya untuk menyelesaikan logical design dari sistem informasi. Analis mendesain prosedur data entri yang akurat sehingga data masuk ke dalam sistem informasi dengan benar. (5) Mengembangkan dan mendokumentasikan piranti lunak.Dalam fase ini sistem analis bekerja dengan programmer untuk mengembangkan piranti lunak original yang dibutuhkan. Beberapa teknik pengembangan dan pendokumentasian piranti lunak meliputi structure chart, nassi-shneiderman chart, dan pseudocode. (6) Pengetesan dan perawatan sistem.Sebelum sistem informasi bisa digunakan, sistem tersebut harus dites. Karena dengan pengetesan biaya yang dibutuhkan lebih rendah untuk menemukan masalah dibanding dengan ketika sistem sudah digunakan oleh user. (7) Implementasi dan evaluasi sistem, Dalam fase terakhir ini, sistem analis membantu pengimplementasian sistem informasi, meliputi pelatihan user menangani sistem. Proses ini mengkonversikan file dari format lama ke format baru, atau membangun sebuah basis data, install equipment.

\section{Unified Modeling Language}

Perancangan sistem pendukung keputusan yang dibuat dalam penelitian ini adalah perancangan sistem pendukung keputusan yang berbasis objek (Object Oriented). Dalam merancang sebuah sistem yang berbasis objek, salah satu hal yang dibutuhkan adalah Unifed Modeling Language (UML).UMLadalah keluarga notasi grafis yang didukung oleh meta-model tunggal yang membantu pendeskripsian dan desain sistem perangkat lunak, khususnya sistem yang dibangun menggunakan pemrograman berorientasi objek. (Fowler, 2005). UML merupakan standar yang relatif terbuka yang dikontrol oleh Object Management Company (OMG), sebuah konsorsium terbuka yang terdiri dari banyak perusahaan. Berikut ini adalah macam-macam notasi grafis dalam UML: (1)Use Case Diagram, Use caseadalah teknik untuk merekam persyaratan fungsional sebuah sistem(Fowler, 2005). Use case mendeskripsikan interaksi tipikal antara pengguna sistem dengan sistem itu sendiri, dengan memberi sebuah narasi tentang bagaimana sistem tersebut digunakan. Use case diagram menampilkan aktor mana yang menggunakan use case mana, use case mana yang memasukkan use case lain dan hubungan antara aktor dan use case. (2)Activity Diagram, Activity diagramadalah teknik untuk menggambarkan logika prosedural, proses bisnis, dan jalur kerja(Fowler, 2005). Dalam beberapa hal, activity diagram memainkan peran mirip dengan diagram alur, tetapi perbedaan prinsip antara notasi dengan diagram alur adalah activity diagram mendukung behaviour parallel. Node pada sebuah activity diagram disebut sebagai action, sehingga diagram tersebut menampilkan sebuah activity yang tersusun dari action. (3)Sequence Diagram, Sequence diagram menurut adalah grafik dimensi yaitu objek ditunjukkan dalam dimensi horizontal, sedangkan lifeline ditunjukkan dalam dimensi vertikal (Munawar, 2005). (4)Class Diagram, Class diagrammerupakan himpunan dari objek-objek yang sejenis(Munawar, 2005). Sebuah objek memiliki keadaan sesaat (state) dan perilaku (behaviour). State sebuah objek adalah kondisi objek tersebut yang dinyatakan dalam attribute/properties. Sedangkan perilaku suatu objek mendefinisikan bagaimana sebuah objek bertindak atau beraksi dan memberikan 
reaksi. (5)Collaboration diagram, Collaboration diagram adalah perluasan dari objek diagram (Munawar, 2005). Objek diagram menunjukkan objek-objek yang hubungannya satu dengan yang lain. Collaboration diagram menunjukkan message-message objek yang dikirim satu sama lain. (6)Component Diagram, Component diagram mempresentasikan dunia riil item yaitu component software (Munawar, 2005). Component software adalah bagian fisik dari sebuah sistem karena menetap di komputer. Component diagram mengandung component, interface, dan relationship.

\section{Data Mining}

Definisi dari Data mining adalah salah satu teknik atau ilmu untuk menemukan pola dari data dalam jumlah besar, sumber data yang dapat digali dalam data mining dapat bersumber dari database, data warehouse, atau penyimpanan informasi lainnya. Data mining berkaitan dengan bidang ilmuilmu lain, seperti database system, data warehousing, statistik, machine learning, information retrieval, dan komputasi tingkat tinggi. Selain itu, data mining didukung oleh ilmu lain seperti neural network, pengenalan pola, spatial data analysis,image database, signal(Han \& Kamber, 2006). Ada beberapa definisi dari data mining yang dikenal di buku-buku teks data mining, diantaranya adalah: (1)Suatu rangkaian proses untuk menggali nilai tambah berupa ilmu pengetahuan yang selama ini tidak diketahui secara manual dari suatu kumpulan data (Pramudiono, 2012). (2) Data mining, sering juga disebut sebagai knowledge discovery in database (KDD), KDD adalah kegiatan yang meliputi pengumpulan, pemakaian data historis untuk menemukan keteraturan, pola atau hubungan dalam set data berukuran besar (Santosa, 2007). (3)Secara sederhana data mining adalah penambangan atau penemuan informasi baru dengan mencari pola atau aturan tertentu dari sejumlah data yang sangat besar (Davies \& Beynon, 2004).

Sedangkan, karakteristik data mining adalah:(1)Data mining berhubungan dengan penemuan sesuatu yang tersembunyi dan pola data tertentu yang tidak diketahui sebelumnya. (2)Data mining biasa menggunakan data yang sangat besar. Biasanya data yang besar digunakan untuk membuat hasil lebih dipercaya. (3).Data mining berguna untuk membuat keputusan yang kritis, terutama dalam strategi(Davies \& Beynon, 2004).

Secara umum, tugas data mining dapat diklasifikasikan menjadi dua kategori, deskriptif (descriptive mining) dan prediktif (predictive mining)(Han \& Kamber, 2006): (1)Predictive mining, bertujuan untuk memprediksi nilai sebuah atribut yang penting berdasarkan nilai dari atribut yang lainnya. Atribut yang diprediksi biasanya dikenal sebagai target atau dependent variable, sedangkan atribut yang digunakan untuk melakukan prediksi dikenal dengan explanatory atau independent variable. Predictive modeling task dibagi menjadi dua tipe yaitu: Classification digunakan untuk memprediksi nilai dari target variable yang discrete (diskret) dan regression digunakan untuk memprediksi nilai dari target variable yang continue (berkelanjutan). (2)Descriptive mining, bertujuan untuk menghasilkan pola (correlations, trends, clusters, trajecttories dan anomalies) yang merangkum keterhubungan dalam data.

\section{Teknik Klasifikasi Dengan Naive Bayes}

Naïve Bayes adalah salah satu algoritma dan salah satu teknik dalam data mining dengan menggunakan klasifikasi statistik yang dapat memprediksi nilai atribut kelas suatu anggota probabilitas. Teorema Bayes dikemukakan oleh Thomas Bayes pada abad ke 18, ia merupakan seorang pendeta presbyterian yang ahli dalam bidang probabilitas. Thomas Bayes mengajukan pertanyaan berikut: “Apakah Tuhan benar-benar ada?” Karena ketertarikannya pada ilmu matematika, ia coba mengembangkan sebuah rumus untuk menentukan probabilitas Tuhan benar-benar ada berdasarkan fakta yang terdapat di bumi. Kemudian oleh Laplace hasil penemuan Bayes tersebut disempurnakan dan diberi nama Teorema Bayes (Leung, 2007). 
Naïve bayes classifier merupakan suatu klasifikasi probabilitas sederhana yang didasarkan pada pengaplikasian teorema Bayes dengan asumasi yang kuat (naïve) dan bebas (independence)(Ian et. al., 2005). Algoritma pada klasifikasi Naive Bayes ini memanfaatkan teori probabilitas dengan cara memprediksi probabilitas di masa depan berdasarkan pengalaman di masa sebelumnya. Nä̈ve Bayes inilah yang digunakan dalam machine learning sebagai metode untuk mendapatkan hipotesis dalam pengambilan sebuah keputusan. Adapun persamaan klasifikasi Naive Bayes adalah sebagai berikut:

$$
P\left(C_{i} \mid X\right)=\frac{P\left(X \mid C_{i}\right) P\left(C_{i}\right)}{P(X)}
$$

$C_{i}=$ Atribut kelas untuk nilai yang ada pada data training

$X=$ Data sampel pada nilai atribut

$P\left(X \mid C_{i}\right)=$ Peluang data sampel $X$, terhadap nilai kelas pada atribut kelas

$P(X)=$ Peluang data sampel pada nilai atribut yang diamati

$P\left(C_{i}\right)=$ Peluang hipotesa dari atribut kelas untuk nilai yang ada pada data training

Naive Bayes merupakan bagian yang dapat memprediksi probabilitas pengalaman di masa sebelumnya secara matematika, pengalaman-pengalaman sebelumnya ini merupakan sekumpulan data training. ( Banerji and Saxena. 2012). Sedangkan data yang akan diprediksi probabilitasnya dengan naive bayes disebut data test atau dengan kata lain, data test merupakan data yang bukan bagian dari data training dan merupakan data yang akan diuji. Setiap data training dan data test merupakan kumpulan dari beberapa atribut dan atribut value. Atribut termasuk atribut kelas, atribut kelas pada data test inilah yang nantinya akan ditemukan berapa nilai atributnya (value). Jika diketahui sekumpulan data training sebagaimana pada tabel 1 dengan atribut kelas adalah buys_computer sebagai berikut:

Tabel 1 Contoh Data Training

\begin{tabular}{cccccc}
\hline id & Age & Income & Student & Credit_rating & Class : buys_computer \\
\hline $\mathbf{1}$ & $<30$ & High & No & Fair & No \\
$\mathbf{2}$ & $<30$ & High & No & Excellent & No \\
$\mathbf{3}$ & $30-40$ & High & No & Fair & Yes \\
$\mathbf{4}$ & $>40$ & Medium & No & Fair & Yes \\
$\mathbf{5}$ & $>40$ & Low & Yes & Fair & Yes \\
$\mathbf{6}$ & $>40$ & Low & Yes & Excellent & No \\
$\mathbf{7}$ & $30-40$ & Low & Yes & Excellent & Yes \\
$\mathbf{8}$ & $<30$ & Medium & No & Fair & No \\
$\mathbf{9}$ & $<30$ & Low & Yes & Fair & Yes \\
$\mathbf{1 0}$ & $>40$ & Medium & Yes & Fair & Yes \\
$\mathbf{1 1}$ & $<30$ & Medium & Yes & Excellent & Yes \\
$\mathbf{1 2}$ & $30-40$ & Medium & No & Excellent & Yes \\
$\mathbf{1 3}$ & $30-40$ & High & Yes & Fair & Yes \\
$\mathbf{1 4}$ & $>40$ & Medium & No & Excellent & No \\
\hline
\end{tabular}

Dari data training tersebut, akan dicari prediksi probabilitas dengan Naive Bayesuntuk data test pada tabel 3.2 untuk menentukan nilai dari atribut kelas buys_computer pada data test.Data test tersebut adalah sebagai berikut: 
Tabel 2 Contoh Data Test

\begin{tabular}{cccclc}
\hline id & Age & Income & Student & Credit_rating & Class : buys_computer \\
\hline $\mathbf{1}$ & $<30$ & Medium & Yes & Fair & $\mathrm{X}$ \\
\hline
\end{tabular}

Dari tabel 1, diketahui terdapat empat atribut yaitu, age, income, student, dan credit_rating. Kelasnya adalah buys_computer yang memiliki dua nilai, yaitu yesdan no. Untuk menentukan kelas pada data test tersebut perlu dihitung nilai kemungkinannya yang dapat diketahui dari datatraining.Berdasarkan persamaan naive bayes, nilai Ci pada Tabel 1 dan Tabel 2 adalah yes dan no yang merupakan nilai dari atribut kelas buys_computer, sedangkanposterior $\mathrm{X}$ untuk $P\left(X \mid C_{i}\right)$ pada tabel 3.1 dan tabel 3.2 adalah atribut age yang memiliki nilai $<30,30-40,>40$, atribut income yang memiliki nilai Low, medium, dan high, atribut student yang memiliki nilai yes dan no, atribut credit_rating yang memiliki nilai fair dan excellent. Maka nilai $P\left(C_{i}\right)$ adalah sebagai berikut:

Nilai $\mathrm{P}\left(C_{\text {i }}\right)$ untuk yes atau no adalah:

$\mathrm{P}($ buys_computer $=$ yes $)=9 / 14=0.643$

$\mathrm{P}($ buys_computer $=$ no $)=5 / 14=0.357$

adalah:

Langkah berikutnya adalah menghitung $\mathrm{P}(\mathrm{X} \mid \mathrm{Ci})$ untuk seluruh data training dari1 sampai 14

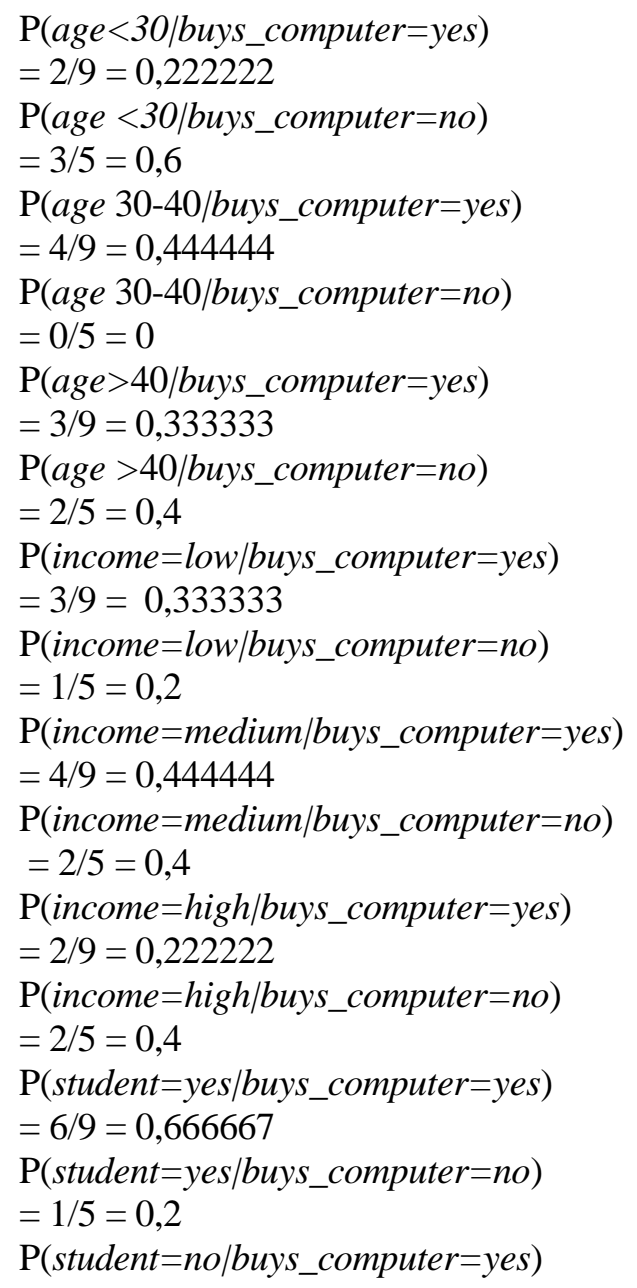




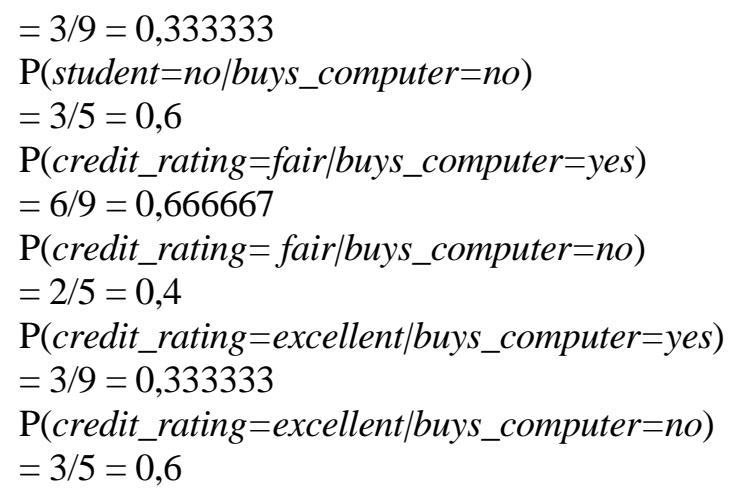

Berdasarkan hasil peluang di atas, maka probabilitas prediksi untuk atribut kelas buys_computer yes atau no berdasarkan rumus naive bayes adalah sebagai berikut:

$\mathrm{P}(\mathrm{X} \mid$ buys_computer $=$ yes $)$

$=0,222222 * 0,444444 * 0,333333 * 0,333333 * 0,444444 * 0,222222 * 0,666667 * 0,333333 * 0.666667$

* 0,333333

$=5,35232 \times 10^{-5}$

$\mathrm{P}(\mathrm{X} \mid$ buys_computer $=$ no $)$

$=0,6 * 0 * 0,4 * 0,2 * 0.4 * 0,4 * 0,2 * 0,6 * 0,4 * 0,6=0$

$\mathrm{P}(\mathrm{X} \mid$ buys_computer $=y e s) \mathrm{P}($ buys_computer=yes $)$

$=5,35232 \times 10^{-5} * 0.643$

$=3,44078 \times 10^{-5}$

$\mathrm{P}(\mathrm{X} \mid$ buys_computer $=$ no $) \mathrm{P}($ buys_computer $=$ no $)$

$=0 * 0.357=0$

Berdasarkan penghitungan di atas maka dapat disimpulkan bahwa, besarnya probabilitas untuk nilai yes pada kelas buys_computer adalah 3,44078 x $10^{-5}$ dan besarnya probabilitas untuk nilai no pada kelas buys_computeradalah 0. Karena probabilitas untuk nilai yes lebih besar daripada probabilitas untuk nilai no, maka nilai $\mathrm{X}$ darikelas untuk data test yang belum diketahui akan masuk kategori buys_computer $=y$ es. Hal ini berarti untuk data test dengan age $=<30$, income $=$ medium, student = yes, credit_rating = fair, maka nilai atribut kelas untuk buys_computer $=$ yes.

\section{Weka}

Weka merupakan singkatan dari Waikato Environment for Knowledge Analysis. Weka adalah sebuah perangkat lunak data mining open source berbasis Java yang memiliki kemampuan sekumpulan algoritma standar data mining. Perangkat lunak ini dapat digunakan untuk melakukan pre-processing, klasifikasi, clustering (pengelompokan), regresi, association rule mining (ARM) dan visualisasi. Weka dapat dijalankan dengan basis GUI atau secara langsung melalui command line (untuk advance user). Aplikasi ini dikembangkan pertama kali oleh Universitas Waikato di Selandia Baru sebelum menjadi bagian dari Pentaho. Weka yang dipakai dalam penelitian ini adalah Weka versi 3.6.

Berdasarkan hasil perhitungan dengan teknik naive bayes yang telah dilakukan, Dwiki Dio

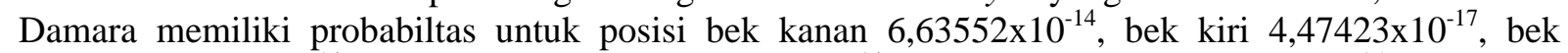
tengah $3,34227 \times 10^{-14}$, gelandang bertahan $1,10404 \times 10^{-14}$, gelandang kanan $3,09587 \times 10^{-15}$, gelandang kiri $1,91103 \times 10^{-13}$, gelandang serang $1,37511 \times 10^{-13}$, gelandang tengah $7,86929 \times 10^{-13}$, goalkeeper $2,53517 \times 10^{-17}$, libero $1,78896 \times 10^{-14}$, second striker $2,28304 \times 10^{-14}$, stopper $5,52624 \times 10^{-14}$, striker $1,03241 \times 10^{-12}$, wing back 4,63804 $\times 10^{-14}$. Karena nilai probabilitas terbesar terdapat pada posisi striker dengan nilai probabilitas $1,03241 \times 10^{-12}$, sehingga dapat ditarik kesimpulan bahwa Dwiki Dio Damara direkomendasikan untuk posisi striker. 


\section{Spesifikasi Teknologi yang Dibutuhkan}

Berikut ini adalah usulan dari spesifikasi teknologi yang dibutuhkan untuk menjalankan usulan rancangan sistem yang akan dibuat :

Perangkat keras (hardware):

- Processor Inter Core i3.

- Hard disk 500GB.

- Keyboard.

- Mouse.

- Memory 2GB.

- Layar monitor 14”.

- Printer.

Perangkat Lunak (software):

- My SQL.

- XAMPP.

- Domain dan web hosting.

\section{SIMPULAN}

Hasil dari penelitian ini adalah rancangan sistem pendukung keputusan untuk menentukan posisi pemain dalam sepak bola. Sistem pendukung keputusan ini sangat membantu para pelatih di SSB Tunas Patriot Bekasi karena sistem pendukung keputusan ini dibuat sesuai dengan kebutuhan dan memiliki tampilan sistem yang mudah dipahami oleh penggunanya. Rancangan sistem pendukung keputusan yang dibuat dalam penelitian ini terdapat halaman utama yang menampilkan informasi umum mengenai SSB Tunas Patriot Bekasi seperti alamat sekertariat, jadwal dan tempat latihan, serta kompetisi yang diikuti oleh SSB Tunas Patriot Bekasi. Pemain dapat mendaftarkan dirinya untuk mengikuti tes penentuan posisi dan pemain yang sudah mengikuti tes penentuan posisi dapat melihat hasil tes berupa rekomendasi posisi dan rincian perhitungan hasil tes untuk menentukan posisi pemain dengan menggunakan teknik naive bayes.

Pelatih dapat masuk ke dalam sistem dengan terlebih dahulu mendaftarkan dirinya ke dalam sistem pendukung keputusan. Setelah pelatih login ke dalam sistem pendukung keputusan, pelatih dapat melakukan edit biodata pelatih, edit biodata pemain, hapus biodata pemain, input hasil tes pemain, edit hasil tes pemain, hapus hasil tes pemain. Di dalam sistem pendukung keputusan, pelatih juga dapat melihat daftar posisi pemain, dan daftar skill pemain. Pelatih juga dapat melihat hasil rekomendasi penentuan posisi pemain dan rincian perhitungan hasil tes untuk menentukan posi pemain dengan menggunakan teknik naive bayes dari hasil tes pemain yang telah di input sebelumnya.

Berdasarkan analisa terhadap sistem penentuan posisi pemain yang berjalan di SSB Tunas Patriot Bekasi, sistem pendukung keputusan untuk menentukan posisi pemain yang terkomputerisasi sangat membantu dalam peningkatan efektifitas kerja pelatih maupun pemain dan efisiensi waktu maupun efisiensi dalam manajemen kerja pelatih, karena sistem pendukung keputusan yang diusulkan dalam penelitian ini mampu mengoptimalkan beberapa proses, antara lain: (1) Sistem pendukung keputusan dapat membantu pemain mempermudah proses pendaftaran pemain dan mempermudah pemain dalam mengetahui posisi yang direkomendasikan dari hasil tes yang telah dilakukan dalam jangka waktu yang singkat. (2) Sistem pendukung keputusan dapat mengoptimalkan kinerja pelatih dalam hal manajemen data pemain dan mengurangi penggunaan kertas. Kinerja pelatih lebih efektif dan efisien karena sistem pendukung keputusan membantu pelatih untuk menentukan posisi pemain dengan cepat setelah pelatih melakukan tes terhadap pemain yang sudah mendaftar sebelumnya dan 
melakukan input data ke dalam sistem. (3) Sistem pendukung keputusan dapat membantu pelatih untuk menggali informasi dan potensi pemain dari banyaknya data yang telah tersimpan sebelumnya sehingga dapat memberikan kontribusi terhadap perkembangan pemain maupun terhadap perkembangan tim.

Untuk pengembangan penelitian berikutnya, sebaiknya analisa yang dilakukan juga mempertimbangkan keadaan fisik pemain seperti tinggi dan riwayat cedera pemain serta mempertimbangkan faktor psikologis pemain sebagai salah satu atribut yang digunakan untuk bahan analisa. Analisa dilakukan dengan menggunakan tools sofware My SQL server. Peneliti juga mengusulkan saran yang dapat digunakan untuk pengembangan penelitian berikutnya, yaitu membuat sebuah aplikasi sistem pendukung keputusan berbasis web dari rancangan yang telah dibuat dalam penelitian ini.

\section{DAFTAR PUSTAKA}

B. Santosa.(2007). Data Mining Teknik Pemanfaatan Data Untuk Keperluan Bisnis. Yogyakarta: Graha Ilmu.

Davies \& P. Beynon. Database Systems. 3rd Edition. New York : Palgrave Macmillan, 2004.

E. Turban. et al. (2005).Introduction to Information Technology. 3rd Edition. USA: John Wiley \& Sons, Inc.

G. A. Gorry \& M.S.Morton. (1971).A Framework for Management Information Systems. USA: Sloan Management Review.

G. Banerji and K. Saxena. (2012). A Comparative Analysis Of Bayesian Methods For Real Estate Domain. International Journal Physical and Social Science, 2(9): 554 - 565.

H. Ian et. al. (2005). Data Mining: Practical machine learning tools and techniques. 2nd Edition. San Francisco: Morgan Kaufmann.

I. Pramudiono. (2006). Pengantar Data Mining: Menambang Permata Pengetahuan di Gunung Data. Diakses 4 September 2014 dari http://www.ilmukomputer.org/wpcontent/uploads/2006/08/iko-datamining.zip.

J. E. Kendall \& K. E. Kendall. (2005). System Analysis and Design. 6th Edition. New Jersey: Pearson Education.

J. Han \& Kamber, M. (2006). Data Mining: Concept and Techniques. 2nd Edition. San Francisco: Morgan Kaufmann Publishers.

Kusrini. (2007). Konsep dan Aplikasi Sistem Pendukung Keputusan. Yogyakarta: CV Andi Offset.

K. M. Leung. (2007). Naive Bayesian Classifier. Diakses 4 September 2012 http://cis.poly.edu/ mleung/FRE7851/f07/naiveBayesianClassifier.pdf.

K. Suryadi\& A. Ramdhani. (1998). Sistem Pendukung Keputusan. Bandung: PT. Remaja Rosdakarya.

Munawar. (2005). Pomodelan Visual dengan UML. Yogyakarta : Graha Ilmu.

M. Fowler. (2005). UML Distilled. 3rd Edition. Yogyakarta: Andi. 